\title{
The Integrated Spatial Assessment of the Flood Hazard Using AHP-GIS: The Case Study of Gorontalo Regency
}

\author{
Muhammad Ramdhan Olii ${ }^{1}$, Aleks Olii ${ }^{1}$ and Ririn Pakaya ${ }^{2}$ \\ ${ }^{1}$ Department of Civil Engineering, Universitas Gorontalo, Limboto, Gorontalo, Indonesia \\ ${ }^{2}$ Department of Public Health, Universitas Gorontalo, Limboto, Gorontalo, Indonesia
}

Received: $2020-11-15$ Accepted: 2021-02-23

\author{
Keywords: \\ AHP; \\ GIS; \\ Flood Hazard; \\ Gorontalo Regency
}

Correspondent email:

kakaramdhanolii@gmail.com

\begin{abstract}
Mapping of potential flood hazards is an important element in ensuring proper planning of development and implementing flood disaster mitigation efforts for flooded areas. Therefore, this study was conducted to assess the regional-scale flood hazard areas in Gorontalo District using an AHP-GIS integration technique with the focus on factors such as annual rainfall, elevation, slope, soil type, distance to the water bodies, and land-use. The flood hazard was divided into five classes, ranging from very low to very high, and $13.61 \%$ of the total area in Gorontalo Regency is classified as either high or very high. Moreover, the distribution of the hazard was verified and 65 events were recorded to have a level of $90.7 \%$ and this indicates the model is reliable to assess flood hazard. The results showed GIS-AHP integration is a promising method to accurately predict flood-hazard areas, especially in those with limited data.
\end{abstract}

(12021 by the authors. Licensee Indonesian Journal of Geography, Indonesia.

This article is an open access article distributed under the terms and conditions of the Creative Commons

Attribution(CC BY NC) licensehttps://creativecommons.org/licenses/by-nc/4.0/.

\section{Introduction}

Flood is seen globally as the most popular hydrometeorology disaster for several decades with numerous ecological and financial impacts such as the loss of lives and properties usually recorded in the affected flood plain (Cabrera \& Lee, 2020, Danumah et al., 2016, Foudi et al., 2015). According to (Kim \& Kim, 2014), the main factor causing floods is excessive rainfall. Meanwhile, several human activities such as deforestation of the upstream catchment, land degradation, spread and expanded development of settlements and assets in flooding zones (Gigović et al., 2017 and Prasad et al., 2016), poor spatial planning and development of regions, zoning, control of flood territories advancement, limited capacity of drainage or stream, poor management of discharges from reservoirs, and inadequate flood mitigation have also been highlighted to be part of the causes (Danumah et al., 2016).

Flood management is, therefore, very important due to the massive damages usually experienced by the general public and the need for appropriate development and management of land, especially in flood-prone areas which require control construction and dense residential or built-up areas (Büchele et al., 2006). It is impossible to effectively implement flood control efforts without a map showing the distribution of flood hazard levels (Bhatt et al., 2014). This makes the map an important requirement in minimizing the level of flood hazard through sustainable environmental management and mitigation efforts before and after a flood (Gigović et al., 2017;Bhatt et al., 2014). It also makes the hazard zones accessible to planners for effective perusal towards regulating their mitigation procedures (Ajin et al., 2013).
There is a rare application of GIS-based multi-criteria analysis in the context of flood risk estimation up to the year 2000 (Kazakis et al., 2015). Meanwhile, several multi-criteria analyses have been developed and applied in susceptibility, risk, and hazard mapping for floods in recent years. For example, Analytic Hierarchy Process (AHP) is one of the popular qualitative methods applied to predict floods through RS modeling in a GIS environment and the spatial measurement of multidimensional elements to form integrated AHP-GIS (Bathrellos et al., 2017). Some other methods have also been reported such as susceptible flood mapping (Lawal et al., 2012, Tehrany et al., 2013, Prasad et al., 2016, Lee et al., 2018), flood risk mapping, hazard flood mapping (Ajin et al., 2013; Gigović et al., 2017; Paquette \& Lowry, 2012; Rahmati et al., 2016; Siddayao et al., 2014; Stefanidis \& Stathis, 2013) , and several others. However, even though some were able to produce acceptable results with different parameters, there is a need for an improvement based on the disadvantages observed. The AHP is, therefore, recommended for regional studies while a global solution and transferable method is required in flood applications (Fernández \& Lutz, 2010). Several studies have been conducted on flood hazards and effective modeling technique through the use of GIS which was discovered to have a good degree of accuracy and suitable to analyze other hazard situations (Gigović et al., 2017; Tehrany et al., 2013). It is possible to easily apply this AHP-GIS method to areas with limited data and it was also found to be reasonable for this type of research based on its ability to adequately oversee enormous volumes of spatial data, thereby, saving cost and time (Djordjević et al., 2014). The delegation of weights to 
criteria by experts in AHP has the ability to cause bias in the final map despite the possibility of conducting a sensitivity analysis to explore the effect of the changes in weight on the criteria and, subsequently, the results (Rahmati et al., 2016). Therefore, the AHP flood-hazard zone map was found to be quite reliable by assuming a hydraulic model of inundation maps (Rahmati et al., 2016). Moreover, Gigović et al. (2017) confirmed $87.1 \%$ of the recorded historical flood sites are on very high flood-prone zones. This confirmed the reliability of the proposed methodology and also affirms the certainty of the results of this analysis. This means the use of the AHPGIS in determining the criteria weights is justified due to its ability to successfully exploit ambiguities and objectively reflect the perceptions of experts (Gigović et al., 2017).

The data obtained from the National Disaster Management Agency in 2019 showed that hydrometeorological disasters constituted over $90 \%$ of the total disasters recorded in Indonesia with $27 \%$ or 385 out of 1426 found to be due to flood. Moreover, the total flood disasters between 2010-2019 were 6,410 events or 641 per year and the impact was quite enormous with the total death toll recorded to be 9,817 people. The causative factors include high rainfall due to the placement of the country in a tropical climate, wide variations in landscape morphology, and worsening damage to the environment.

Gorontalo Regency is the second-highest regency with the most flood disasters in Gorontalo Province. This was observed from the records of the Regional Disaster Management Agency which showed North Gorontalo to have experienced 35 events, Gorontalo had 34, Boalemo had 23, Bone Bolango had 17, Pohuwato had 11, and Gorontalo City had 9 events over the past 10 years. It was also discovered that 53,546 people suffered and were displaced, 334 units of houses damaged, 7,748 units of houses inundated, 3 units of health facilities, and 5 units of educational facilities were also damaged. The high number recorded in Gorontalo Regency shows flood is a serious problem in the area which requires adequate preventive measures to minimize its occurrence. This, therefore, means the central and regional governments need to participate effectively in the mitigation efforts through several policies on flood management.

Flood hazard has been predicted in some studies using complex variables but it is difficult to apply their results in other areas with limited data. This means the model to be developed needs to have a procedure to analyze the uncertainty associated with spatial inputs. For example, Stefanidis \& Stathis (2013) assessed flood hazard in the catchment area of Northern Greece using anthropogenic factors such as land-use, rock erodibility, watersheds slope, main stream slope, rock permeability, watershed shape, and density of hydrographic network as well as natural factors such as encroachments, inadequate technical works, and shaped cross-section at the plain area of the stream. Moreover, Ajin et al. (2013) analyzed the distribution of flood hazards in Vamanapuram River Basin, Kerala, India using seven factors including drainage density, land use or land cover, soil type, micro watershed size, average annual rainfall, slope, and roads per micro watershed. Siddayao et al. (2014) also evaluated the spatial distribution of flood hazard in Enrile municipality through the use of several variables such as the distance from the access road, land-use zoning, drainage density, distance to drainage, soil type, distance from urban areas, resident precipitation or rainfall, landform, slope or elevation, population density, and land cover or vegetation.

Gigović et al. (2017; Paquette \& Lowry (2012); Rahmati et al. (2016) do not consider rainfall as one of the important factors affecting flood. Meanwhile, rainfall has a role in flood

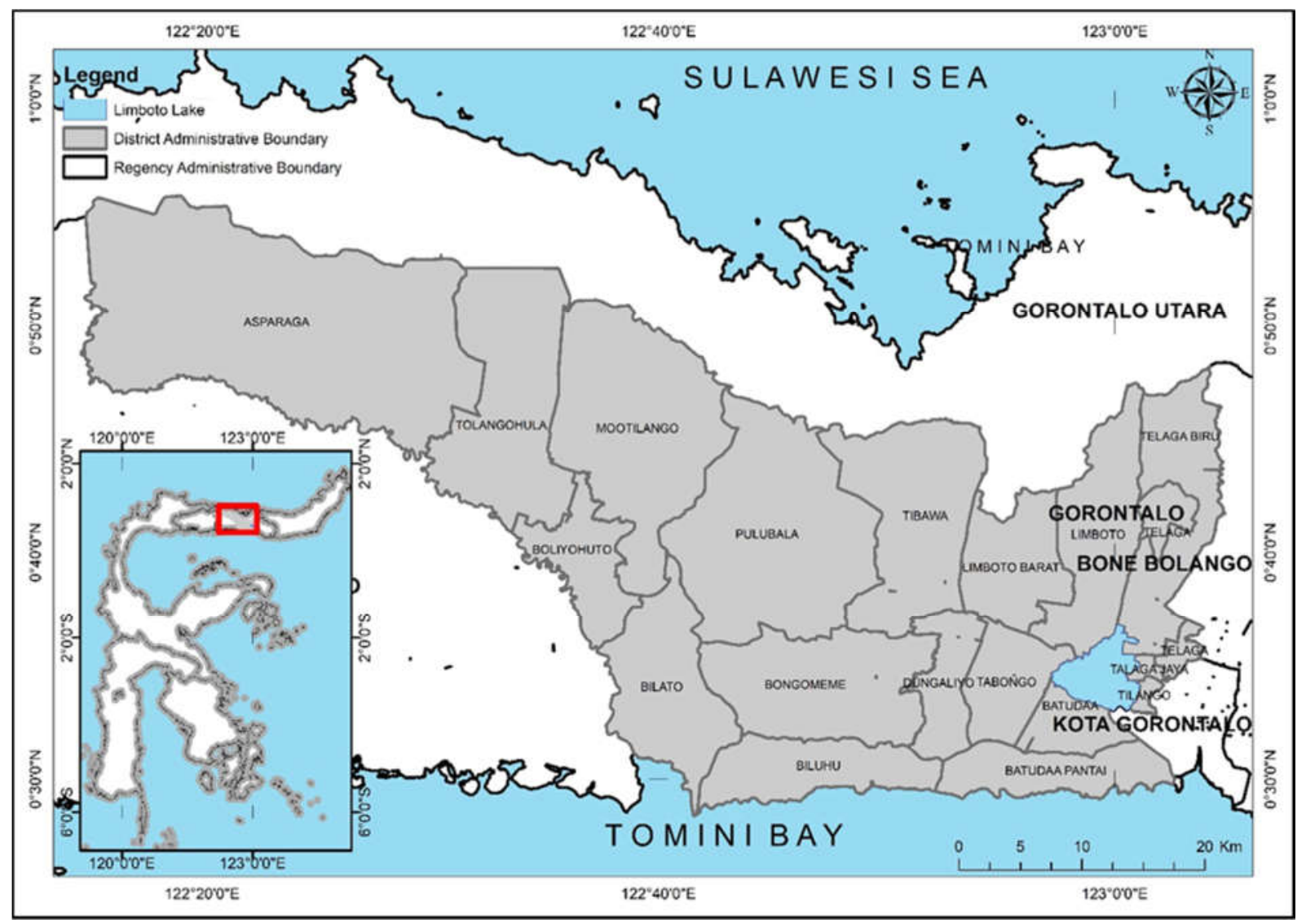

Figure 1. Location of Study area 
events in tropical areas like Gorontalo. Therefore, this research was conducted to analyze the classes of flood hazard distribution mapping for the Gorontalo Regency using an AHP-GIS integration method with several factors such as the annual rainfall, elevation, slope, soil type, distance to the water bodies, and land use. The purpose is majorly to determine the damages usually caused by flooding.

\section{Method}

\section{Study Area}

Gorontalo Regency is located in the middle of Gorontalo Province between $0^{\circ} 28^{\prime} 23.22^{\prime \prime}$ and $0^{\circ} 55^{\prime} 44.08^{\prime \prime}$ South latitudes and $122^{\circ} 14^{\prime} 43.69^{\prime \prime}$ and $123^{\circ} 4^{\prime} 48.27^{\prime \prime}$ East longitudes as indicated in Figure 1. It has 19 districts and 205 villages with an area of $2159 \mathrm{~km}^{2}$. The total population is 373.858 persons with a population density of 187 persons $/ \mathrm{km}^{2}$. The regency is topographically surrounded by hills with a flat area in the middle and most of its area is dominated by forest and shrubs. Moreover, the surface altitude of the area ranges between 0 and $2,062 \mathrm{~m}$ and it is considered to have a tropical climate with maximum, minimum, and average annual rainfall of $2,318 \mathrm{~mm}, 1,260 \mathrm{~mm}$, and $1,707 \mathrm{~mm}$, respectively. The average daily minimum temperature is $21.5^{\circ} \mathrm{C}$ and the maximum is $34.5^{\circ} \mathrm{C}$. In the east of Gorontalo, there is Limboto Lake which is the estuary of 23 streams in Limboto Watershed.

\section{Data}

The factors used in this study were obtained from rainfall data stations, soil maps, topographic maps, land use maps, and historical flood events and manipulated using GIS. They were represented by raster models with a $30 \times 30 \mathrm{~m}^{2}$ grid in the GIS environment. Digital Elevation Model (DEM) was constructed for the stream, slope, and elevation as the base for other topographic-related analyses. The DEM was generated from https://earthexplorer.usgs.gov/. Meanwhile, the data on rain was observed to be very rare due to the conditions of several rainfall gauge stations in the area, therefore, annual rainfall data were obtained on different periods between 2014 and 2019 for each station from the Meteorology, Climatology, and Geophysics Agency and the Central Stream Region II Sulawesi Agency. Harmonized World Soil Database (HWSD) website which has a shapefile data and linked attribute database with 1:5.000.000 scale were also used to extract soil maps and information. Moreover, land use data were derived from the map obtained from the Gorontalo Regency Regional Development Planning Agency Office 1:25.000 scale (RTRW year 2010-2033) while data on historical flood events were collected from Gorontalo Regency Regional Disaster Management Agency.

\section{Analytical Hierarchy Process (AHP)}

The methodology used to analyze the distribution of flood hazard distribution was a GIS-based spatial assessment in the form of the Analytical Hierarchy Process (AHP) as indicated in Figure 2. The AHP is a decision-making tool developed through several criteria and alternatives selected based on all related criteria using a table-matrix with relevant values (Saaty, 2008). The elements on the matrix table are compared using a preference scale from 1 to 9 to show their level of importance such that 1 means both elements are equally important or two elements have the same effect while 9 indicates one element is absolutely important than the others (Saaty, 2008). These elements are usually created based on the availability of accurate data as well as the knowledge and experience of the decision-maker or expert. For the purpose of this study, experts on flood management and regional development planning were obtained from Central Stream Region II Sulawesi and Gorontalo Regency Regional Development Planning Agencies. Meanwhile, one of the key points in assessing the AHP pairwise comparison matrix is through the evaluation of the consistency ratio (CR) such that a CR value lesser than 0.1 indicates a satisfactory degree of consistency (Saaty, 2008).

The AHP procedure according to Saaty (2008) includes the following

a) Defining the problems and setting goals

b) Arranging the problems into a hierarchy to make the complex ones visible from a detailed and measurable perspective.

c) Prioritizing each problem element in the hierarchy to generate its weight or contribution to the achievement of goals. This means those with the highest weight are prioritized based on a pairwise comparison matrix of all the elements at the same hierarchical level.

d) Conducting a consistency test on the comparison drawn at each hierarchical level and priority synthesization by calculating the eigenvector value for each matrix.

\section{Consistency Check}

The consistency ratio (CR) of the AHP eigenvector matrix was evaluated after it has been created. The value is, however, expected to be $<0.1$ using the following equation.

$$
C R=\frac{C I}{R I}
$$

where $\mathrm{CR}$ is the consistency ratio, $\mathrm{CI}$ is the consistency index, and RI is the random index presented in Table 1. Meanwhile, the CI values are calculated as follows

$$
C I=\frac{\lambda_{\max }-n}{n-1}
$$

where $\lambda_{\max }$ is the maximum eigenvalue of the comparison matrix and $\mathrm{n}$ is the criteria number.

\section{Definition of the Flood Hazard Factor}

The first step in analyzing the spatial distribution of flood hazard levels is to determine the factors causing flooding in the area based on a structured frame of mind to ensure they are all represented. It is also important that the factors are simple in order to minimize the complexity of the model and ease of application. This is usually followed by the selection of the factors influencing the level of flood hazard based on the characteristics of flooding in Gorontalo Regency as follows:

1) Annual rainfall is an important factor in flooding (Kim \& Kim, 2014). The annual rainfall for 2014-2019 was calculated based on 14 rainfall gauge stations located inside and outside Gorontalo Regency as shown in Figure 3. The data at each station was interpolated using the Inverse Distance Weight (IDW) method to obtain the spatial distribution of rainfall patterns in the study area. The annual rainfall values were observed to have varied between a minimum of $<1500 \mathrm{~mm} /$ year and a 


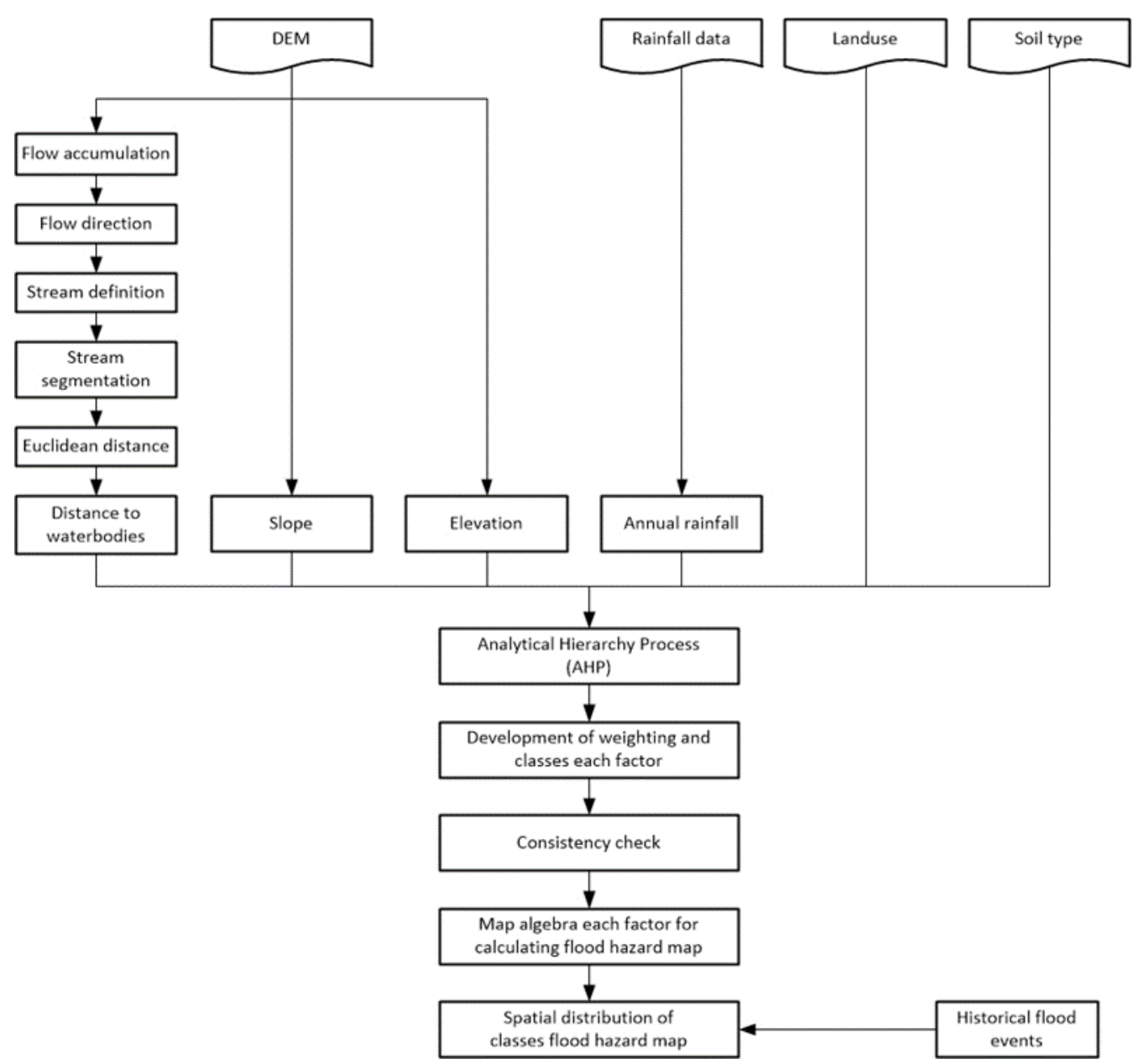

Figure 2. Flowchart of the methodology

Table 1 Random Index (RI) Value

\begin{tabular}{cccccccrrr}
\hline $\mathrm{n}$ & 1 & 2 & 3 & 4 & 5 & 6 & 7 & 8 & 9 \\
\hline $\mathrm{RI}$ & 0.00 & 0.00 & 0.58 & 0.90 & 1.12 & 1.24 & 1.32 & 1.41 & 1.45 \\
\hline
\end{tabular}

maximum of $>2100 \mathrm{~mm} /$ year as shown in Table 4 with the highest recorded in the northern district which is a mountainous area.

2) The elevation of an area is also an important factor affecting the location of flood accumulation. Areas with low elevation are more likely to have more accumulation than those with high elevation. Meanwhile, areas with higher elevations and steeper slopes have the ability to collect surface runoff more slowly than flat areas at lower elevations (Kazakis et al., 2015). Gorontalo Regency is dominated by areas with elevation at $<12.5 \mathrm{~m}$ covering $1063 \mathrm{~km}^{2}$ or $49.61 \%$ as indicated in Table 4, thereby, having the potential to cause large flooding due to its location in a lowland area.

3) The slope is also important to high and low velocity, surface runoff volume, and vertical percolation. This is due to the fact that flat areas retain surface runoff longer in temporary storage. The slope map was, however, designed on DEM using 3D analyst tool as shown in Figure 3 and the study location was discovered to have an almost evenly distributed slope with $437 \mathrm{~km}^{2}$ having $>40 \%, 455 \mathrm{~km}^{2}$ with $25-40 \%, 369 \mathrm{~km}^{2}$ with $15-25 \%$, $315 \mathrm{~km}^{2}$ with $8-15 \%$, and $568 \mathrm{~km}^{2}$ with $<8 \%$ slope as indicated in Table 4 . This means the sloping area is in the middle due to the steep slope surrounding the Gorontalo Regency, thereby, leading to runoff accumulation in the middle area.

4) Soil type is a significant factor influencing surface runoff and infiltration in an area and they both, subsequently, affect flood susceptibility (Ebaid et al., 2016). Surface runoff velocity generally tends to be faster and the volume is usually greater in soils containing a lot of clay than sand and vice versa. A map of soil types is shown in Figure 3 and the study area was observed to be dominated by loamy and sandy soils which cover 1208 $\mathrm{km}^{2}$ or $56.36 \%$ as presented in Table 4 . Therefore, this area has macropores but has low aggregation and this means it has a low ability to hold water and nutrients.

5) Distance to water bodies such as streams, lakes, swamps, etc. is closely related to flood events in an area. Flooding occurs when the surface runoff surplus cannot be accommodated in a waterbody and overflows into the surrounding area. This means the areas located near water bodies and accumulation pathways are more susceptible (Gigović et al., 2017). Most of the areas of Gorontalo District represented by $1394 \mathrm{~km}^{2}$ or $65.05 \%$ of the total area are located far or more than $900 \mathrm{~m}$ from waterbodies as shown in Table 4. Meanwhile, the 

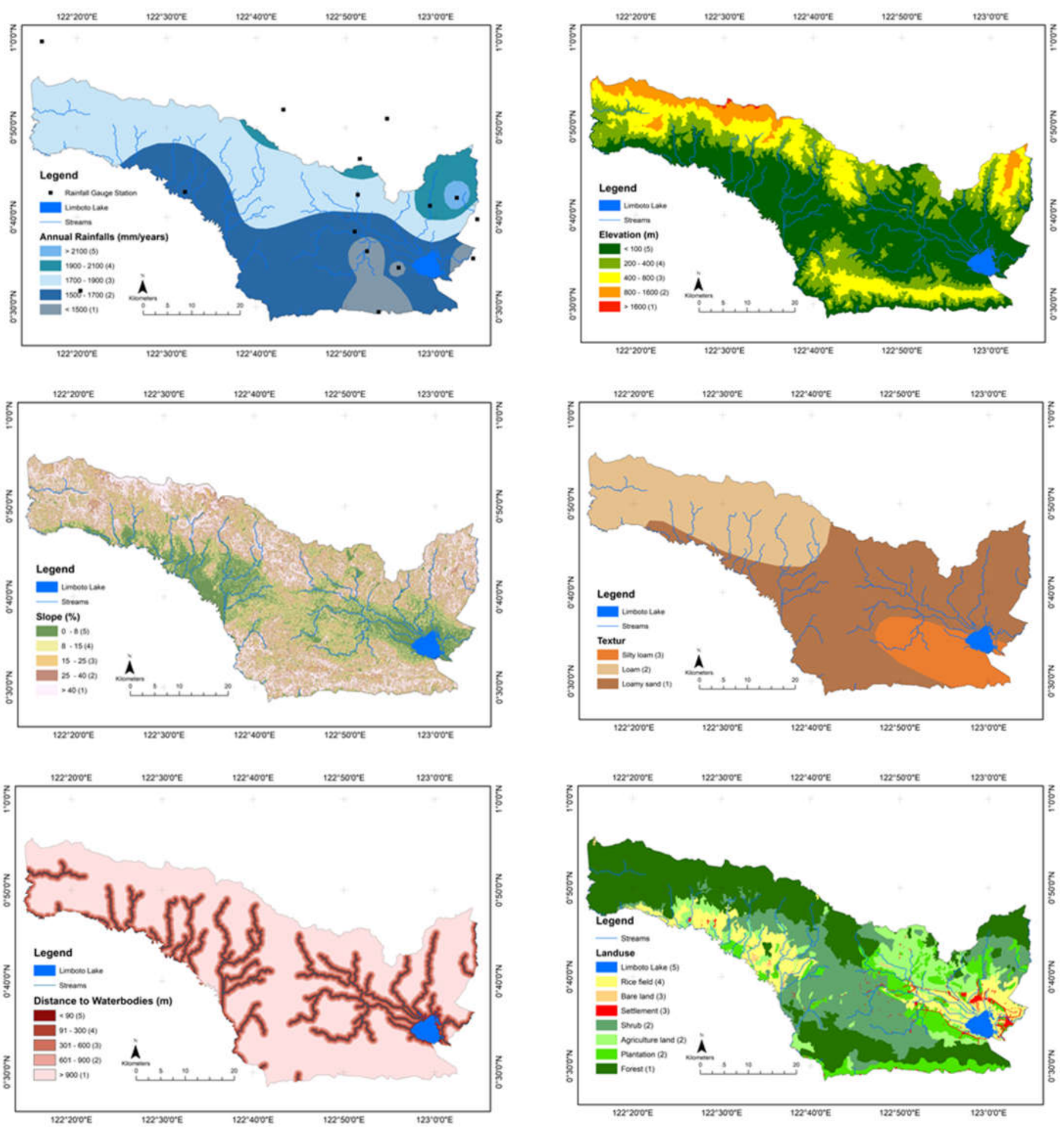

Figure 3. Flood hazard factor maps for Gorontalo Regency

settlement areas are mostly developed close to the water bodies, especially Limboto Lake as shown in the distance map of Figure 3.

6) Land use is also one of the factors contributing to flooding due to its importance to surface runoff, the ability of the soil to store water, and infiltration rate (Gigović et al., 2017). Dense forests and vegetation have been discovered to have the ability to trap water longer and increase infiltration while settlements and bare land increase surface runoff and reduce the rate of infiltration. For this study, land use was classified into eight categories which are shrub, water bodies, forest, plantation, rice field, settlement, agricultural land, and bare land as shown in Table 4 . The forests and shrubs in the steep area of the north and south of Gorontalo Regency were found to be the most dominant as shown in Figure 3.

The pairwise comparisons of the significance criteria in the main eigenvalue are presented in Table 2 while the normalized values of the factors are indicated in Table 3 to obtain the appropriate weight of each.

The natural factors influencing the flood hazard class were determined after which a spatial distribution map was developed for each factor and a flood hazard model was run using Arc GIS software. This involved discretization of each factor and model output into a spatially defined map layer with a smaller homogeneous grid size of $30 \times 30 \mathrm{~m}$. 
Weight Development

A weight value is developed for the factors based on the importance of each in the flood hazard. The weight and rating values for the different classes of the study area were determined according to the local characteristics of each factor. Therefore, the factors with their classes and ratings are represented in Table 4 and the distance to the water body was found to be the most important factor affecting the flood hazard class based on the weight value. This is consistent with the historical event of flooding in Gorontalo Regency where areas closer to water bodies were reported to have experienced more flood events than others. Moreover, elevation had the second-highest weight value due to its influence on the accumulation of surface runoff and it was

Table 2. Flood hazard factors

\begin{tabular}{|c|c|c|c|c|c|c|}
\hline Flood hazard factor & Annual rainfall & Elevation & Slope & Soil Type & $\begin{array}{l}\text { Distance to the } \\
\text { water bodies }\end{array}$ & Land use \\
\hline Annual rainfall & 1.00 & 0.33 & 3.00 & 3.00 & 0.33 & 0.20 \\
\hline Elevation & 3.00 & 1.00 & 4.00 & 7.00 & 0.50 & 3.00 \\
\hline Slope & 0.33 & 0.25 & 1.00 & 3.00 & 0.20 & 0.33 \\
\hline Soil type & 0.33 & 0.14 & 0.33 & 1.00 & 0.14 & 0.14 \\
\hline Distance to the water bodies & 3.00 & 2.00 & 5.00 & 7.00 & 1.00 & 3.00 \\
\hline Land use & 5.00 & 0.33 & 3.00 & 7.00 & 0.33 & 1.00 \\
\hline
\end{tabular}

Table 3. Normalized Flood Hazard Factors

\begin{tabular}{lrrrrrrrr}
\hline \multicolumn{1}{c}{ Flood hazard factor } & $\begin{array}{c}\text { Annual } \\
\text { rainfall }\end{array}$ & Elevation & Slope & Soil Type & $\begin{array}{c}\text { Distance to } \\
\text { the water } \\
\text { bodies }\end{array}$ & Land use & Total & $w_{i}$ \\
\hline Annual rainfall & 0.08 & 0.08 & 0.18 & 0.11 & 0.13 & 0.03 & 0.61 & 0.10 \\
Elevation & 0.24 & 0.25 & 0.24 & 0.25 & 0.20 & 0.39 & 1.57 & 0.26 \\
Slope & 0.03 & 0.06 & 0.06 & 0.11 & 0.08 & 0.04 & 0.38 & 0.06 \\
Soil type & 0.03 & 0.04 & 0.02 & 0.04 & 0.06 & 0.02 & 0.19 & 0.03 \\
Distance to the water bodies & 0.24 & 0.49 & 0.31 & 0.25 & 0.40 & 0.39 & 2.07 & 0.35 \\
Land use & 0.39 & 0.08 & 0.18 & 0.25 & 0.13 & 0.13 & 1.17 & 0.20 \\
\hline
\end{tabular}

Table 4. Weighting and rating values of each class for the study area

\begin{tabular}{|c|c|c|c|c|c|}
\hline Factors & Weighting & Classes & Area $\left(\mathrm{km}^{2}\right)$ & Area (\%) & Rating \\
\hline \multirow{5}{*}{$\begin{array}{l}\text { Distance to the water } \\
\text { bodies }\left(D_{w}\right)\end{array}$} & 0.35 & $>900 \mathrm{~m}$ & 118 & 5.51 & 1 \\
\hline & & $600-900 m$ & 188 & 8.75 & 2 \\
\hline & & $300-600 m$ & 238 & 11.08 & 3 \\
\hline & & $90-300 \mathrm{~m}$ & 206 & 9.60 & 4 \\
\hline & & $<90 \mathrm{~m}$ & 1394 & 65.05 & 5 \\
\hline \multirow[t]{5}{*}{ Elevation $\left(\mathrm{E}_{\mathrm{l}}\right)$} & 0.26 & $>100 \mathrm{~m}$ & 2 & 0.12 & 1 \\
\hline & & $50-100 \mathrm{~m}$ & 126 & 5.89 & 2 \\
\hline & & $25-50 \mathrm{~m}$ & 415 & 19.34 & 3 \\
\hline & & $12.5-25 \mathrm{~m}$ & 537 & 25.03 & 4 \\
\hline & & $<12.5 \mathrm{~m}$ & 1063 & 49.61 & 5 \\
\hline \multirow[t]{4}{*}{ Land use $\left(\mathrm{L}_{\mathrm{u}}\right)$} & 0.20 & Forest & 845 & 39.43 & 1 \\
\hline & & Shrub, plantation, agriculture land & 985 & 45.97 & 2 \\
\hline & & Bare land, settlement & 35 & 1.62 & 3 \\
\hline & & Rice field & 255 & 11.91 & 4 \\
\hline \multirow[t]{5}{*}{ Annual Rainfall $\left(\mathrm{R}_{\mathrm{a}}\right)$} & 0.10 & $<1500 \mathrm{~mm} /$ years & 157 & 7.31 & 1 \\
\hline & & $1500-1700 \mathrm{~mm} /$ years & 865 & 40.36 & 2 \\
\hline & & $1700-1900 \mathrm{~mm} /$ years & 950 & 44.32 & 3 \\
\hline & & $1900-2100 \mathrm{~mm} /$ years & 147 & 6.87 & 4 \\
\hline & & $>2100 \mathrm{~mm} /$ years & 24 & 1.14 & 5 \\
\hline \multirow[t]{5}{*}{ Slope $\left(S_{1}\right)$} & 0.06 & $>40 \%$ & 437 & 20.38 & 1 \\
\hline & & $25-40 \%$ & 455 & 21.22 & 2 \\
\hline & & $15-25 \%$ & 369 & 17.21 & 3 \\
\hline & & $8-15 \%$ & 315 & 14.71 & 4 \\
\hline & & $<8 \%$ & 568 & 26.49 & 5 \\
\hline \multirow[t]{4}{*}{ Soil Type $\left(S_{t}\right)$} & 0.03 & Sand, loamy sand & 1208 & 56.36 & 1 \\
\hline & & Sandy loam, loam & 673 & 31.42 & 2 \\
\hline & & Silty loam, sandy clay loam & 262 & 12.2 & 3 \\
\hline & & $\begin{array}{l}\text { Silty clay loam, clay loam, sandy clay, silty } \\
\text { clay, clay }\end{array}$ & - & - & 4 \\
\hline
\end{tabular}


followed by land use, annual rainfall, slope, and soil type in order of importance.

The overall score of the flood hazard (FR) was computed according to Equation (3) through the use of the weighting values in Table 4 .

$F R=0.35 \times D_{w}+0.26 \times E_{l}+0.20 \times L_{u}+0.10 \times R_{a}+0.06 \times S_{l}+0.03 \times S_{t}$

where $D_{w}$ is the distance to the waterbodies rating, $E_{l}$ is elevation rating, $L_{u}$ is Land use rating, $R_{a}$ is annual rainfall rating, $S_{1}$ is slope rating, and $S_{t}$ is soil type rating.

This study made use of six criteria, therefore, the RI value was found to be 1.24 as indicated in Table 1 based on Equation (3), $\lambda_{\max }$ was 6.50 , CI was 0.099 , and CR was 0.081 or $8.1 \%$. Meanwhile, it is important to note that the judgment is consistent when the CR value is lesser than 0.1 $(10 \%)$ while the assessment requires some revisions when the value exceeds $10 \%$.

\section{Results and Discussion}

Flood Hazard Map

A flood hazard map which combines all the six factors was developed in a model based on Equation 1 using a map algebra tool from the previous section as shown in Figure 4. The map was divided into five levels of hazard which are very high, high, medium, low, and very low and the study area was observed to be in the very low, low, and medium classes with $13.9 \%, 50.37 \%$, and $22.12 \%$, respectively. This means the area is far from the water bodies, has a low slope, and high-density vegetations. Meanwhile, the spatial distribution of high and very high classes was $13.07 \%$ and $0.54 \%$ respectively which is $13.61 \%$ of the total area of the Gorontalo Regency. These districts in these classes include Limboto Barat, Limboto, Telaga Biru, Telaga, Telaga Jaya, Tilango, Batudaa, Tibawa, and Tabongo as observed from their historical records for the 2016-2020 period. Furthermore, the map analysis showed the distance to water bodies is the most important factor followed by elevation, land use, and heavy rainfall.

The red and orange colors in Figure 4 indicate the areas dangerously affected by flooding and observed to be located close to the water bodies. This means the local authorities need to publish information on flood hazard areas in addition to the implementation of technical measures. This can be in the form of campaigns through posters, maps, leaflets, etc., and organization of briefings in schools, city halls, or other public places to inform residents about the hazardous areas. Moreover, the local community is expected to recognize and adapt to early warning signs, follow the

Table 5. Comparison of Flood Hazard Classes Spatial Distribution and Number of Flood Events in Gorontalo Regency

\begin{tabular}{|c|c|c|c|}
\hline Classes of Flood Hazard & $\begin{array}{c}\text { Area } \\
\left(\mathrm{km}^{2}\right)\end{array}$ & $\begin{array}{c}\% \\
\text { Area }\end{array}$ & Historical Flood Events \\
\hline Very low & 163.08 & 13.90 & - \\
\hline Low & $1,079.69$ & 50.37 & 6 \\
\hline Medium & 474.05 & 22.12 & 12 \\
\hline High & 280.19 & 13.07 & 42 \\
\hline Very high & 11.49 & 0.54 & 5 \\
\hline
\end{tabular}

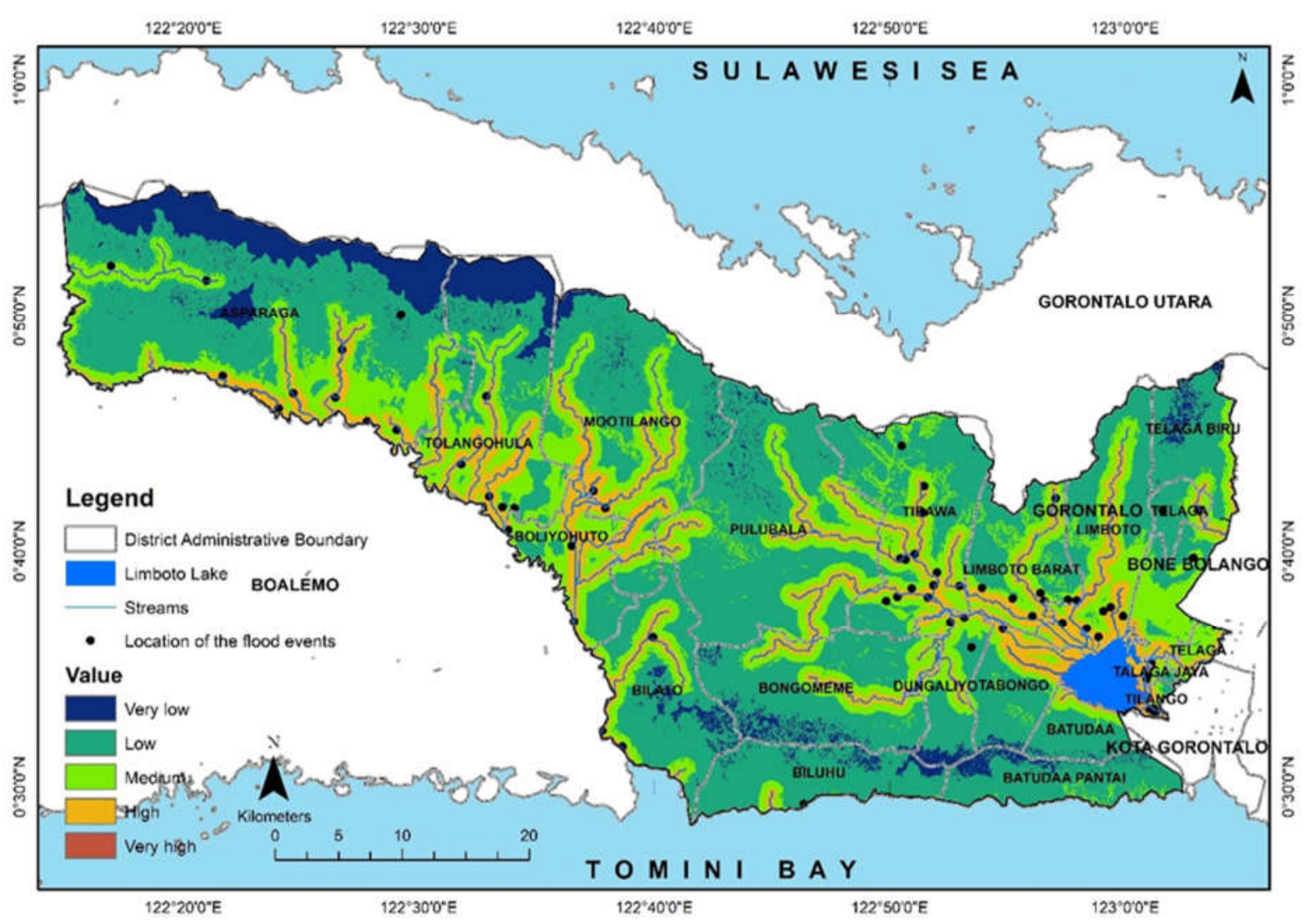

Figure 4. Flood hazard map for Gorontalo Regency 
evacuation plan, and stay far away from these hazardous areas in case of any flood.

Table 5 shows the close relationship between the spatial distribution of flood hazard classes and their respective number of occurrences. The level of flood hazard class was found to be directly proportional to the number of events and the highest frequency out of the 65 occurrences was recorded in the high class. This further proves the validity of the results obtained in this study.

\section{Discussion}

Developing countries such as Indonesia generally have several areas without data and information on flood hazards and historical flood events. Therefore, a simple model was developed in this research to describe the distribution of flood hazard classes in the Gorontalo Regency. This involved the application of the AHP-GIS integration model to estimate the distribution of flood hazard levels towards contributing significantly, in the form of data and methods, to the description of flood location and formulation of mitigation plans in the study area. The validation of the method, comparison of the findings with other studies as well as the advantages and disadvantages of using AHP-GIS are, however, discussed as follows.

\section{Model Validation}

The validation is required determine the spatial relationship between the historical flood events and the hazard maps designed to validate the results obtained through the application of the AHP-GIS. This involved using 65 coordinate locations according to the historical flood events presented by the National Disaster Management Agency of Gorontalo Regency. The evaluation, however, produced a score of $90.7 \%$ as presented in Table 5 and this means the model is reliable.

\section{Comparison of the Results with Other Studies}

Stefanidis \& Stathis (2013) found the regional-scale flood hazard to be influenced by $48 \%$ of anthropogenic factors such as land use, rock erodibility, watersheds slope, mainstream slope, rock permeability, watershed shape, and density of hydrographic network while $42 \%$ was due to natural factors such as encroachments, inadequate technical works, and shaped cross-section at the plain area of the stream. This means most floods are due to human intervention in water bodies, intense tourism development, and extensive urbanization (Stefanidis \& Stathis, 2013). Meanwhile, four natural factors including elevation, annual rainfall, slope, and soil type as well as two anthropogenic factors including the distance of the water bodies and land use were used in this study. The highest weight value of 0.35 or $35 \%$ was recorded with the distance of the water bodies which is an anthropogenic factor due to the fact that it was caused by human intervention or activities. This is in line with the findings of Kazakis et al. (2015) that flood events are influenced by human behavior or operational deficiencies in urban areas.

Kazakis et al. (2015) also found flow accumulation and distance to the stream to have a significant influence on flood hazard with a weight of $30 \%$ and $21 \%$ respectively. The accumulated flow was observed to include the water flowing down-slope into water bodies and the high values recorded indicate the area has concentrated flow and, consequently, higher flood hazard. Meanwhile, waterbody-overflows are also crucial to the initiation of a flood with the inundation often emanating from the water bodies and later expands to the surroundings. Moreover, Gigovic et al. (2017) and Rahmati et al. (2016) also found distance to the river to be a major factor with areas close to waterbodies discovered to be highly prone to floods, and the role of these water bodies was reported to be decreasing as the distance increases (Gigović et al., 2017, Kazakis et al., 2015). It is important to note that there is a Limboto Lake in the area studied in this research with a very high level of sediment affecting its capacity. It also serves as an outlet for twenty-three streams and this makes the area to be on a high flood hazard level. Furthermore, the spatial distribution of historical flooding events in Gorontalo District is presented in Figure 4 and most were observed to be caused by flow accumulation and proximity to water bodies.

Paquette \& Lowry (2012) found elevation to be the most significant factor determining the level of flood hazard with a weight value of 0.4810 or $48 \%$. Floods are controlled by gravity which pulls the water towards low-lying areas and eventually the ocean (Paquette \& Lowry, 2012) and this led to the selection of elevation as the most important input for the model. Meanwhile, Cabrera \& Lee, (2020) and Paquette \& Lowry, (2012) showed the effect of the distance to water bodies was only 0.0543 or $5.43 \%$ and 0,095 or $9.5 \%$ respectively. This, therefore, means an area close to a water body but placed on a high elevation is not usually affected by floods.

\section{Advantages and Disadvantages of Using AHP-GIS}

Carr \& Zwick (2007) defined AHP as a comprehensive decision-making model and its main advantage is to solve multi-objective and multi-criteria problems by comparing the preferences of each criterion in the hierarchical structure. Over the past several decades, the methods commonly used in non-paired weights of GIS modeling have focused on the sequential process of determining the weights and ranking criteria used in a model (Chang, 2010). Meanwhile, the AHP weights were determined by considering multiple pairs and calculating consistency ratio (CR) value to evaluate the weight of the logical criteria which are sometimes ignored in non-paired methods due to the assumption of linearity between the criteria and their weights (Paquette \& Lowry, 2012)

The disadvantage of AHP is that it is subjected to expert judgment as observed in the designation of importance ranking - very important vs absolutely important - even though it uses consistency as a reference to compare the significance of the criteria (Paquette \& Lowry, 2012). Fernández \& Lutz (2010) also investigated the error propagation due to criteria weight recorded by using AHP and concluded that the important factor causing uncertainty in the model was the variation in the two input models with the highest weighting values. These values greatly influence the reliability of the resulting model because they are considered to be absolutely important when compared with the other inputs (Paquette \& Lowry, 2012). This means the reliability and accuracy of the raw data with the highest weight is very important. In the present study, the two top weight values were distance to the water bodies factor with 0.35 and elevation factor with 0.26 . This means they have a total weight value of 0.61 or over $60 \%$ of the influence on the 
classes of flood hazard and their significant effect on the model leads to the provision of accurate data for them. AHPGIS has a simple and practical system to model multiobjective decision-making problems such as natural disasters and urban spatial analysis despite its inability to determine uncertainties (Bathrellos et al., 2017).

\section{Conclusion}

AHP was integrated with GIS in this study to produce a model to evaluate the spatial distribution of flood hazard classes in the Gorontalo Regency after several spatial data have been obtained. It was discovered that the spatial distribution of very low, low, medium, high, and very high classes was $13.9 \%, 50.37 \%, 22.12 \%, 13.07 \%$, and $0.54 \%$ respectively. The high and very high classes were distributed near water bodies especially Limboto Lake due to the fact that the factor with the highest weight value of 0.35 or $35 \%$ was the distance of the water bodies. This influence was, however, observed to be reduced as the distance increases. Moreover, the validation of flood historical events showed the AHP-GIS integration model has a relatively high consistency with a value greater than $90 \%$.

This means spatial data integration and the application of AHP-GIS procedure have the ability to provide detailed flood hazard distribution maps for planning and development agencies, stakeholders, and local governments in managing floods through zoning of the floodplain, estimated damage, and improvement efforts to reduce the disaster. It is also possible to apply this method in other areas having almost similar characteristics to the study area. Further studies need to focus on improving spatial assessment of flood vulnerability and risks in Gorontalo regency using AHP-GIS and also obtain validation results based on hydrology and hydraulic modeling.

\section{Acknowledgment}

The authors appreciate the Engineering Faculty of Universitas Gorontalo for supporting this study.

\section{References}

Ajin, R. S., Krishnamurthy, R. R., Jayaprakash, M., \& Vinod, P. G. (2013). Flood hazard assessment of Vamanapuram River Basin, Kerala, India: An approach using Remote Sensing \& GIS techniques. Advances in Applied Science Research, 4(3), 263274.

Bathrellos, G. D., Skilodimou, H. D., Chousianitis, K., Youssef, A. M., \& Pradhan, B. (2017). Suitability estimation for urban development using multi-hazard assessment map. Science of the Total Environment, 575, 119-134. https://doi.org/10.1016/ j.scitotenv.2016.10.025

Bhatt, G. D., Sinha, K., Deka, P. K., \& Kumar, A. (2014). Flood Hazard and Risk Assessment in Chamoli District, Uttarakhand Using Satellite Remote Sensing and GIS Techniques. International Journal of Innovative Research in Science, Engineering and Technology, 03(08), 15348-15356. https:// doi.org/10.15680/ijirset.2014.0308039

Büchele, B., Kreibich, H., Kron, A., Thieken, A., Ihringer, J., Oberle, P., Merz, B., \& Nestmann, F. (2006). Flood-risk mapping: Contributions towards an enhanced assessment of extreme events and associated risks. Natural Hazards and Earth System Sciences, 6(4), 483-503. https://doi.org/10.5194/nhess-6-4852006

Cabrera, J. S., \& Lee, H. S. (2020). Flood risk assessment for Davao Oriental in the Philippines using geographic information system-based multi-criteria analysis and the maximum entropy model. Flood Risk Manajement, 13, 1-17. https:// doi.org/10.1111/jfr3.12607

Carr, M. H., \& Zwick, P. D. (2007). Smart Land-Use Analysis: The LUCIS Model. Land Use Conflict Identification Strategy. Press, ESRI.

Chang, K. (2010). Introduction to Geographic Information Systems (5th Editio). McGraw Hill.

Danumah, J. H., Odai, S. N., Saley, B. M., Szarzynski, J., Thiel, M., Kwaku, A., Kouame, F. K., \& Akpa, L. Y. (2016). Flood risk assessment and mapping in Abidjan district using multi-criteria analysis ( AHP ) model and geoinformation techniques, ( cote d ' ivoire ). Geoenvironmental Disasters, 3(10), 1-13. https:// doi.org/10.1186/s40677-016-0044-y

Djordjević, S., Vojinović, Z., Dawson, R., \& Savić, D. A. (2014). Uncertainties in flood modelling in urban areas. In Applied Uncertainty Analysis for Flood Risk Management (pp. 297-334). Imperial. https://doi.org/10.1142/9781848162716_0012

Ebaid, H. M., Farag, H. A., \& El Falaky, A. A. (2016). Using GIS and Remote Sensing Approaches to Delineate Potential Areas for Runoff Management Applications in Egypt. International Journal of Environmental Science and Engineering, 7, 85-93.

Fernández, D. S., \& Lutz, M. A. (2010). Urban flood hazard zoning in Tucumán Province, Argentina, using GIS and multicriteria decision analysis. Engineering Geology, 111(1-4), 90-98. https://doi.org/10.1016/j.enggeo.2009.12.006

Foudi, S., Osés-Eraso, N., \& Tamayo, I. (2015). Integrated spatial flood risk assessment: The case of Zaragoza. Land Use Policy, 42, 278-292. https://doi.org/10.1016/j.landusepol.2014.08.002

Gigović, L., Pamučar, D., Bajić, Z., \& Drobnjak, S. (2017). Application of GIS-interval rough AHP methodology for flood hazard mapping in Urban areas. Water (Switzerland), 9(6), 126. https://doi.org/10.3390/w9060360

Kazakis, N., Kougias, I., \& Patsialis, T. (2015). Assessment of Flood hazard areas at a regional scale using an index-based approach and Analytical Hierarchy Process $囚$ : Application in Rhodope Evros region, Greece. Science of the Total Environment, 538, 555-563. https://doi.org/10.1016/j.scitotenv.2015.08.055

Kim, B. S., \& Kim, H. S. (2014). Evaluation of flash flood severity in Korea using the modified flash flood index (MFFI). Journal of Flood Risk Management, 7(4), 344-356. https://doi.org/10.1111/ jfr3.12057

Lawal, D. U., Matori, A. N., Hashim, A. M., Yusof, K. W., \& Chandio, I. A. (2012). Detecting Flood Susceptible Areas Using GIS-based Analytic Hierarchy Process. Paper Presented at the 2012 International Conference on Future Environment and Energy IPCBEE., 28, 1-5.

Lee, S., Lee, S., Lee, M. J., \& Jung, H. S. (2018). Spatial assessment of urban flood susceptibility using data mining and geographic information system (GIS) tools. Sustainability, 10, 1-19. https:// doi.org/10.3390/su10030648

Paquette, J., \& Lowry, J. (2012). Flood hazard modelling and risk assessment in the Nadi River Basin, Fiji, using GIS and MCDA. The South Pacific Journal of Natural and Applied Sciences, 30(1), 33-43. https://doi.org/10.1071/sp12003

Prasad, A. S., Pandey, B. W., Leimgruber, W., \& Kunwar, R. M. (2016). Mountain hazard susceptibility and livelihood security in the upper catchment area of the river Beas, Kullu Valley, Himachal Pradesh, India. Geoenvironmental Disasters, 3(1), 117. https://doi.org/10.1186/s40677-016-0037-x

Rahmati, O., Zeinivand, H., \& Besharat, M. (2016). Flood hazard zoning in Yasooj region, Iran, using GIS and multi-criteria decision analysis. Geomatics, Natural Hazards and Risk, 7(3)(19 May 2015), 1000-1017. https:// doi.org/10.1080/19475705.2015.1045043

Saaty, T. L. (2008). Decision making with the analytic hierarchy process. International Journal Services Sciences, 1(1), 83-98. https://doi.org/10.1504/IJSSCI.2008.017590

Siddayao, G. P., Valdez, S. E., \& Fernandez, P. L. (2014). Analytic Hierarchy Process (AHP) in Spatial Modeling for Floodplain Risk Assessment. International Journal of Machine Learning 
and Computing, 4(5), 450-457. https://doi.org/10.7763/ ijmlc.2014.v4.453

Stefanidis, S., \& Stathis, D. (2013). Assessment of flood hazard based on natural and anthropogenic factors using analytic hierarchy process (AHP). Natural Hazards, 68(2), 569-585. https:// doi.org/10.1007/s11069-013-0639-5

Tehrany, M. S., Pradhan, B., \& Jebur, M. N. (2013). Spatial prediction of flood susceptible areas using rule based decision tree (DT) and a novel ensemble bivariate and multivariate statistical models in GIS. Journal of Hydrology, 504, 69-79. https://doi.org/10.1016/j.jhydrol.2013.09.034 